Sari Pediatri, Vol. 8, No. 4, Maret 2007: 294 - 298

\title{
Hepatitis Akibat Penyakit Sistemik
}

\author{
Dedy Gumilang Daulay, ${ }^{*}$ Supriatmo, ${ }^{*}$ Atan Baas Sinuhaji **
}

\begin{abstract}
Abstrak
Hati merupakan organ parenkim terbesar yang sering terlibat akibat penyakit sistemik. Pada beberapa penyakit sistemik, hati dapat lebih bertahan dibanding organ tubuh lainnya. Dalam mengevaluasi pasien dengan disfungsi dan penyakit sistemik, klinisi harus dapat membedakan apakah gangguan hati yang terjadi akibat penyakit sistemik, akibat obat yang digunakan dalam terapi penyakit sistemik tersebut ataupun bersamaan dengan penyakit hati primer.
\end{abstract}

Kata kunci: Hepatitis, penyakit sistemik

$\mathcal{H}$ ti menerima 25\% dari seluruh cairan yang beredar pada sirkulasi tubuh manusia. Hati merupakan organ parenkim yang sering menjadi sasaran akibat penyakit sistemik. Hati menjadi organ metabolik komplek dengan fungsi sintesis dan detoksifikasi. Letak dan ukuran hati dalam sistem sirkulasi, menjadikannya organ yang sering terlibat pada penyakit sistemik, gangguan sirkulasi, dan inflamasi. ${ }^{1,2,3-6}$ Meskipun demikian hepatitis yang terjadi akibat penyakit sistemik tidak dapat atau sulit dibedakan dengan hepatitis primer yang memang terjadi akibat kelainan primer di hati. Hepatitis akibat penyakit sistemik bisa terjadi akibat pengaruh penyakit sistemik tersebut atau akibat proses pengobatan penyakit hati tersebut. Obat-obatan yang bersifat hepatotoksik sering harus diberikan kepada seorang pasien akibat tidak tersedia obat yang aman buat hati,

\footnotetext{
Alamat korespondensi:

Dr. Atan Baas Sinuhaji, Sp.A(K).

Subbagian Gastroenterologi-Hepatologi IKA FK - USU / RSHAM Medan,

Dr. Dedy Gumilang Daulay

Bagian Ilmu Kesehatan Anak FK USU / RSHAM Jl. Bunga Lau No. 17

Telepon: (061) 8361721, Fax.: (061) 8361721

E-mail: bikafkusu@telkom.net. Kotak Pos 697 Medan-20136
}

tetapi jika kita yakin gejala-gejala penyakit hati yang timbul berhubungan dengan pemakaian obat maka obat harus dihentikan segera agar tidak terjadi gagal hati. ${ }^{1,3,6,7,8}$

Hati merupakan organ yang memegang peran sentral untuk metabolisme termasuk obat-obatan. Oleh karena itu obat secara umum berpotensi untuk menyebabkan kerusakan hati. Penyakit hati akibat obat (PHAO) dilaporkan merupakan $18 \%$ penyebab gagal hati akut di Amerika Serikat dan lebih kurang sama di negara sedang berkembang. ${ }^{2}$ Kejadian PHAO ini juga merupakan $25 \%$ penyebab gagal hati fulminan dan biasanya disertai dengan kolestasis akut. ${ }^{3}$ Sampai saat ini tidak diketahui secara pasti insidens hepatitis akibat penyakit sistemik.

Dalam tulisan ini akan dibahas mengenai etiologi, beberapa contoh penyakit sistemik yang berpengaruh pada hati, diagnosis, gambaran klinis dan tata laksana hepatitis akibat penyakit sistemik.

\section{Etiologi}

Beberapa penyakit sistemik yang dapat mengakibatkan hepatitis adalah akibat kegagalan sirkulasi seperti pada penyakit gagal jantung kongestif, hepatitis iskemik dan perikarditis konstriktiva. Selain itu beberapa penyakit 
sistemik lainnya seperti penyakit hematologi, penyakit kolagen vaskular, penyakit endokrin, penyakit susunan syaraf pusat, dan penyakit gangguan nutrisi dapat menyebabkan hepatitis sebagai penyakit penyerta. ${ }^{4-7}$

\section{Kegagalan sirkulasi}

Terjadinya penurunan aliran darah ke hati, peningkatan tekanan vena hepatik dan hipoksia arteri, merupakan faktor utama terjadinya hepatitis akibat kegagalan sirkulasi. Pada kasus dengan syok berat terjadi penurunan tekanan darah yang menyebabkan situasi seperti trauma hati akut atau sering disebut sebagai hepatitis iskemik. ${ }^{5-7}$

Diperkirakan 20\% dari bayi baru lahir yang menderita penyakit jantung kongenital yang meninggal sebelum menginjak usia 1 bulan, mengalami kelainan hati pada pemeriksaan otopsi. Sindrom jantung hipoplastik kiri dan koartatio aorta merupakan penyakit terbanyak. Hepatitis iskemik berhubungan dengan penurunan curah jantung, tetapi hipotensi sering tidak didapatkan. Hepatitis iskemik ini lebih sering terlihat pada anak yang mendapat operasi bypass cardiopulmonal. ${ }^{5}$

Hepatitis iskemik ini ditandai dengan peningkatan yang cepat dari serum transaminase dalam 24-48 jam setelah terjadi iskemia. ${ }^{5}$ Konsentrasi enzim serum berada pada 5000 - 10.000 IU/L. Alkali phospatase normal. Hepatomegali, jaundice dan koagulopati terdapat pada $25 \%$ - 50\% anak dengan hepatitis iskemik. $^{5}$

\section{Penyakit hematologi}

Penyakit hematologi yang sering menyebabkan kelainan pada hati adalah hemoglobinopati yang ditandai dengan anemia, hepatomegali, peningkatan enzim hati dan berberapa derajat ikterus. Terjadinya peningkatan konsentrasi bilirubin indirek adalah replesi dari hemolisis, sedangkan konsentrasi bilirubin direk merupakan indikasi terjadinya penyakit hati. ${ }^{5-7}$

Penyakit hati terjadi akibat berbagai faktor yang bervariasi, peningkatan bilirubin terjadi akibat hemolisis yang terjadi, transfusi darah berulang menyebabkan penderita terpapar dengan virus hepatotropik dan overload besi, sedangkan anemia kronik yang terjadi dan overload besi sendiri mengakibatkan disfungsi miokard, yang akhirnya merupakan suatu lingkaran untuk terjadinya iskemia hepar..$^{5-7}$

Penyakit hematologi lain yang sering menyebabkan penyakit hati kronis pada anak dan orang dewasa adalah penyakit sickle cell. Pada otopsi $90 \%$ kasus sickle cell mengalami hepatomegali, distensi sinusoid, hiperplasia sel Kupffer dengan eritrogenositosis dan nekrosis parenkim fokal.,

Penyakit koagulasi dapat menyebabkan hepatitis karena pasien penyakit ini terpapar sering dengan produk darah yang mengandung virus hepatotropik. Insidens hepatitis $\mathrm{C}$ pada penyakit koagulasi berkisar 60\%-90\%.-10 Dilaporkan 20\% kasus hemofilia mengalami gangguan hati persisten dan secara histologis dapat terjadi hepatitis kronis persisten sampai hepatitis kronis aktif bahkan bisa menjadi sirosis. Kontak dengan darah yang mengandung virus HIV berkisar 25\%-76\%, walaupun infeksi HIV dapat menyebabkan abnormalitas pada hati. ${ }^{5-7}$

Pada limfoma, leukemia dan neuroblastoma terjadi abnormalitas hati dengan beberapa faktor yang mempunyai kontribusi seperti infiltrasi tumor, obstruksi intrahepatik/ekstrahepatik, obat kemoterapi, dan malnutrisi energi protein. ${ }^{5-7}$ Pada transplantasi sumsum tulang, gangguan hati yang terjadi dapat akibat faktor tumor, regimen kemoterapi, infeksi, sludge bilier, nutrisi parenteral, VOD dan GVHD (graftversus-host-disease). ${ }^{5}$

\section{Penyakit kolagen vaskular}

Gangguan pada hati dapat bersifat primer maupun sekunder terutama akibat obat-obat yang digunakan. Pada artritis reumatoid juvenil, obat-obatan yang diberikan sering mengakibatkan kerusakan pada hati. Transaminase serum menjadi meningkat mencapai $60 \%$ pada anak yang mendapat obat salisilat jangka panjang terutama pada anak yang lebih muda dengan penyakit sistemik. ${ }^{5}$

\section{Sindrom lupus eritematosus dan penyakit jaringan ikat}

Terlibatnya organ hati pada penyakit sindrom lupus eritematosus mencapai 25\%-33\%. Pasien umumnya menunjukkan gejala hepatomegali, ikterus, dan peningkatan enzim hati. Demikian pula pada penyakit yang mengenai jaringan ikat sering melibatkan organ hati dengan peningkatan transaminase serum. ${ }^{5,6,11-13}$ 


\section{Penyakit endokrin}

Pada penyakit endokrin seperti hipopituitarisme diketahui dapat menyebabkan hepatitis. Hormon pituitari terlibat dalam pengaturan sekresi dan aliran empedu. Studi eksperimental menunjukkan hormon tiroid dan kortisol mengakibatkan asam lemak tidak tergantung pada aliran empedu. Pada neonatus dengan hypopituitarism dapat terjadi hepatitis secara biokimia dan histologik. ${ }^{4-6}$

Kasus diabetes dua pertiga diantaranya menunjukkan gangguan hati. Spektrum lesi histologis termasuk dengan peningkatan deposisi glikogen pada hepatosit, steatosis, deposisi hialin dan fibrosis yang akhirnya menuju ke sirosis. ${ }^{5-7}$

Hepatitis terjadi pada 15\%-75\% pasien hipertiroid, sebagai akibat efek toksik langsung tiroksin yang menyebabkan hipoksia pada jaringan yang mengakibatkan kerusakan pada zona sentralobular. Sedangkan pada hipotiroid terjadi penurunan konsumsi oksigen pada hati yang mengakibatkan penurunan produksi asam empedu, aliran, dan garam empedu. ${ }^{5,6}$

\section{Sepsis}

Kolestasis intrahepatik yang sering terjadi pada sepsis menyebabkan gangguan pada transpor asam lemak dan anion organik pada hepatosit. Selain itu pada sepsis endotoksin dilepaskan ke dalam darah menyebabkan terangsangnya kaskade sitokin yang berasal dari leukosit dan makrofag. ${ }^{7,8}$

\section{Obat-obatan, alkohol dan bentuk lain selain alkohol}

Penyakit hati akibat obat (PHAO) sering kali menunjukkan reaksi berat ataupun fatal. Obat dapat menyebabkan kerusakan hati karena efek toksik langsung (intrinsik) atau reaksi yang tak diduga (idiosinkrasi). Gambaran klinis tersering adalah hepatitis, kolestasis, atau gabungan hepatitiskolestasis. ${ }^{14}$

Berbagai preparat hepatotoksin intrinsik yang hebat telah lama dikeluarkan dari penggunaan klinis seperti karbontetraklorida, kloroform dan asam tanat. Sejumlah obat dengan potensi hepatotoksik intrinsik masih digunakan seperti asetaminofen dan besi anorganik, dapat bersifat hepatotoksik jika digunakan dalam jumlah besar. Contoh lain adalah tetrasiklin dan $\mathrm{L}$ asparaginase yang merupakan hepatotoksin sitotoksik bila digunakan dalam dosis tinggi yang dapat menyebabkan steatosis mikrovesikular. ${ }^{14-16}$ Pemberian antikonvulsan seperti difenilhidantoin, fenobarbital, dan karbamazepin dapat menyebabkan peningkatan transaminase serum namun jarang menyebabkan hepatotoksisitas yang berat. ${ }^{4-7,14,16}$

Steatosis hepatik merupakan suatu keadaan terjadinya gambaran patologi secara histologik pada hati yang diakibatkan oleh obat-obatan, alkohol, bahan lain non alkohol (NASH=non-alcoholic steatohepatitis), dan kegemukan. Patogenesis hepatitis dan fibrosis yang diakibatkan oleh alkohol diduga melalui peroksidase lipid. Metabolisme etanol menyebabkan terbentuknya ROS (reactive oxygen species) dan karbon radikal bebas yang mampu merangsang peroksidase dari rantai cabang asam lemak tidak jenuh pada membran fospolipid dan lipoprotein. Demikan pula pada NASH yang secara patogenesis terjadi peroksidase lemak yang mekanismenya penting dalam terjadinya steatohepatitis. ${ }^{17-19,24,25}$

\section{Penyakit susunan syaraf pusat}

Anak dengan gangguan pada susunan saraf pusat dapat menyebabkan gangguan pada hati. Penyakit susunan saraf pusat sepertihypoxic ischaemic encephalopathy (HIE) menyebabkan iskemia hati dengan terjadinya peningkatan transaminase dan waktu perdarahan yang memanjang. ${ }^{4-6}$

\section{Penyakit nutrisi}

Beberapa penyakit nutrisi yang dapat menyebabkan hepatitis adalah penyakit celiac, kegemukan, bypass saluran cerna, dan malnutrisi. Nutrisi parenteral juga dapat menyebabkan hepatitis.,5 Pada kegemukan terjadi distribusi mikrovesicular dan menyebabkan penghambatan oksidasi mitokondria dan asam lemak dengan mekanisme yang berbeda-beda. ${ }^{4-6,17,20-22}$ Namun sebagian besar kasus obesitas dengan disfungsi hati tidak menunjukkan gejala. ${ }^{5,6}$ Penyebab terjadinya gangguan hati pada penyakit celiac tidak jelas tetapi diduga gambaran hati berhubungan dengan pasase antigen melalui mukosa saluran cerna yang mengalami trauma. ${ }^{4-6}$ 


\section{Gambaran Klinis}

Hepatitis sekunder akibat penyakit sistemik memberikan gambaran yang sama dengan hepatitis primer. Namun tidak jarang gejala klinis kelainan di hati lebih menonjol dibanding penyakit sistemik yang mendasari, sehingga tidak jarang pasien diobati hanya sebagai pasien hepatitis tanpa memikirkan kenyataan hepatitis yang terjadi hanyalah sekunder akibat penyakit sistemik. Pada sebagian kasus hepatitis akibat penyakit sistemik, gejala yang timbul merupakan gabungan dari gejala penyakit sistemik yang mendasarinya dengan gejala penyakit hati. $2,3,8,9$

\section{Diagnosis}

Tidak ada parameter khusus yang menunjukkan derajat gagal hati kongestif dengan peningkatan transaminase serum. Serum aspartate aminotransferase (AST) biasanya lebih tinggi dibandingkan alanine aminotransferase (ALT), tetapi hal ini tidaklah mutlak. Ikterus yang terjadi pada pasien dengan asites dan hepatomegali tetapi tidak mempunyai stigmata terhadap penyakit hati kronis seperti telengiektasia, palmar eritem dan dilatasi vena-vena abdominal superfisial perlu dipertimbangkan sebagai petunjuk telah terjadi congestive hepatopathy. ${ }^{6}$

Indikator terbaik untuk menentukan telah terjadinya gangguan hati akibat amiloidosis adalah melalui biopsi hati. Walaupun lebih dari 25\% kasus SLE menunjukkan kelainan pada pemeriksaan uji fungsi hati namun biopsi hati menunjukkan lesi minimal yang relatif. Penderita SLE dengan gangguan hati umumnya tidak menunjukkan gejala. Walaupun jarang SLE pada seseorang dapat menyebabkan penyakit hati yang serius. ${ }^{6,11-13}$

Fungsi tiroid yang abnormal diketahui berhubungan dengan penyakit autoimun seperti hepatitis autoimun. Saat ini diketahui penyakit tiroid diduga berhubungan dengan hepatitis $\mathrm{C}$ dan bisa merupakan komplikasi pengobatan akibat terbentuknya antibodi antitiroid. ${ }^{4-6}$

Terjadinya gangguan hati pada penyakit hematologi disebabkan oleh berbagai faktor seperti terjadinya peningkatan bilirubin oleh hemolisis, pemberian transfusi yang berulang. Dalam melakukan evaluasi terhadap kasus limfoma dengan penyakit hati, harus ditentukan apakah klinis atau biokimia terbukti penyakit hati merupakan akibat penyakit primer yang memerlukan terapi reinduksi atau tidak berhubungan sama sekali dengan tumor. Jika tidak berhubungan dengan tumor biasanya akibat terpapar dengan agen kemoterapi yang bersifat hepatotoksik, trauma radiasi dan infeksi. ${ }^{5,6}$

Diagnosis hepatitis/penyakit hati akibat penyakit sistemik perlu dipikirkan apakah hepatitis yang terjadi sejalan dengan adanya penyakit sistemik. Misalnya jika hepatitis terjadi pada seorang pasien tuberkulosis harus dipikirkan apakah hepatitis yang terjadi itu akibat penyakit atau akibat obat yang digunakan atau juga merupakan kelainan hati primer yang tidak berhubungan sama sekali dengan penyakit tuberkulosis yang diderita. Namun sayangnya hal itu sangatlah sulit untuk menentukannya. . $, 4,6,7,9$

\section{Tata laksana}

Tidak ada penatalaksanaan yang khusus terhadap hepatitis yang diakibatkan penyakit sistemik ini. Tatalaksana umumnya ditujukan pada penyakit primer yang menyebabkannya. ${ }^{4-7,17-19}$ Pengobatan dengan menggunakan vitamin $\mathrm{E}$ pada NASH telah dilakukan pada anak dan hasilnya dapat menurunkan aminotransferase serum dan fosfatase alkalin pada keadaan normal. ${ }^{26}$

Hepatitis akibat obat dapat sembuh 14 hari setelah obat dihentikan. ${ }^{1}$ Demikian juga hepatitis akibat pemberian nutrisi parenteral total akan sembuh jika

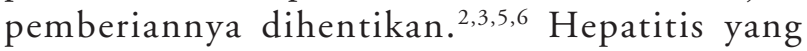
berhubungan dengan penyakit jantung juga akan sembuh jika penyakit jantung terkontrol dengan baik sepanjang belum terjadi kerusakan hati permanen ataupun telah terjadi gagal hati. 1,5,7,8,10

\section{Kesimpulan}

Pada kasus yang menderita penyakit kronik dan mengalami gangguan pada hati perlu dipikirkan hubungan antara penyakit sistemik dengan kelainan hati tersebut. Bisa saja kelainan hati yang terjadi sekunder akibat penyakit sistemik ataupun akibat obatobatan untuk mengatasi penyakit sistemik tersebut. Sampai saat ini belum ada pemeriksaan spesifik yang dapat membedakan penyakit hati primer dengan penyakit hati yang disebabkan oleh penyakit sistemik. 
Oleh karena itu, pengobatan penyakit hati akibat penyakit sistemik ditujukan untuk pengobatan penyakit dasar dan tata laksana penyakit hati secara umum.

\section{Daftar Pustaka}

1. Grendel JH. The liver in systemic disease. Dalam : Friedman LS, Keeffe EB, Maddrey WC, penyunting. Handbook of liver disease. Edisi ke 3. Edinburgh : Churchill Livingstone, 1998. h. 305-13

2. Ostapowicz G, Fontana RJ, Larson AM, DavemT, Lee WM. The Acute Liver Failure Study Group. Etiology and outcome of acute liver failure in the USA: preliminary results of a prospective multi-centre study. Hepatology 1999; 30:221A.

3. Hoofnagle JH, Carithers RL, Shapiro C. Fulminant hepatic failure summary of a workshop. Hepatology 1995; 21:240-52.

4. Beath SV. The liver in systemic illnes. Dalam: Kelly DA, Sherlock DS editor. Deseases of the liver and biliary system in children. Edisi ke-1.Blackwell science ltd; 1999. h. 213-25

5. Farrel MK, Buenvalor JC. Sistemic disease and the liver. Dalam: Sucky FJ, penyunting. Liver disease in children. St. Louis: Mosby, 1994. h. 580-97.

6. Dickson RC. The liver in systemic disease. Dalam: O'Grady JG, Lake JR, Howdle PD, penyunting. Comprehensive Clinical Hepatology. London: Mosby, 2000

7. Schwimmer J, Balistreri W. Liver disease associated with sistemic disease. Dalam: Behrman RE, Kliegman RM, Jenson HB, penyunting. Nelson textbook of pediatrics, edisi ke-17. Philadelphia: Saunders, 2004. h. 1333-5.

8. Lin D.B, Tsai. T.P, Chen W.K. Seroprevalence of hepatitis $C$ virus infection and its association with natural infection of hepatitis B virus among preeschool children in taiwan. Eropean journal of epidemiology 2003; 18:245-9.

9. Sehgal S, Allen PLJ. Hepatitis C in children. Pediatric Nursing 2004; 30:409.

10. Schuval S, Dyke RB, Lindsey J. Hepatitis C in children with perinatal human immonodeficiency virus infection enrolled in along-term follow up protocol. Archieves of pediatrics and adolescent medicine 2004; 158:1007.

11. Hahn BH. Management of systemic lupus erythematosus. Dalam: Kelly WN, Harris ED, Rudy S, Sledge CB, penyunting. Textbook of rheumatology vol 2. Edisi ke5 Philadelphia, WB Saunders Co, 1997. h. 534-40.
12. Klippel JH. Treatment of systemic lupus erythematosus .Dalam: Klippel JH, Weyand CM, Wortmann RL, penyunting. Primer on the rheumatic desease. Edisi ke-11.Atlanta, Arthritis foundation, Georgia 1997. h. 258-62.

13. Lee.LA, Sokol RJ, Buyon JP. Hepatobiliary disease in neonatal lupus: Prevalence and clinical characteristic in cases enrolled in a national registry. Pediatrics 2002; 109: pp e 11 .

14. Marino G, Zimmerman HJ, Lewis JH. Management of drug induced liver desease. Current Gastroenterol report 2001; 3:38-48

15. King PD, Perry MC . Hepatotoxicity of chemotherapy. The oncologist 2001; 6:162-76.

16. Zimmerman HJ . Drug induced liver desease. Clin Liver Dis 2000; 4:73-96.

17. Bolder U, Ton-Nu HT, Schteingart CD, Frick E dan Hoffmam AF. Hepatocyte Transport bile acids and organic anions in endotoxemic rate : impaired uptake and Secretion. Gastroenterol 1997; 112:214-25.

18. Day CP, James OFW. Steatohepatitis: a tale of two hits. Gastroenterol 1998; 114:842-5.

19. Berson A, Beco VD, Letteron P, Robin MA, Moreau C, Kahwaji JE, dkk. Steatohepatitis inducing drugs cause mitochondrial dysfunction and lipid peroxidation in rat hepatocytes. Gastroenterol 1998; 114:764-74.

20. Strauss RS, Barlow SE, Dietz W. Prevalence of abnormal serum aminotransferase Values in overweight and obese adolescents. J Pediatr 2000; 136:727-33.

21. Franzese A, Vajro P, Argenziano A. Liver involment in obese children: Ultrasonography and liver enzyme levels at diagnosis and during follow-up an italian population. Digest dis and science 1997; 42:1428-32.

22. Straus RS. Comparison of serum concentration of a tochoperol and b-carrotene in a cross- sectional sample of obese and non obese children (NHANES III). J Pediatr 1999; 134:160-5.

23. Moseley RH. Sepsis-associated cholestasis. Gastroenterology 1997; 112:302-5.

24. Pineiro-Carrero VM, Pineiro EO. Liver. Pediatrics 2004; 113:1097-106.

25. Montini G, Carasi C, Zancan L, Dall'Amico R, Murer L, Zacchello G. Chronic cholestatic liver disease with associated tubulointerstitial nephropathy in early childhood. Pediatrics 1997; 100:p.e1-10.

26. Lavine JE. Vitamin E treatment of nonalcoholic steatohepatitis in children: a pilot study. J Pediatr 1999; 12:734-8. 